\title{
Evidences of autologous fat grafting for the treatment of keloids and hypertrophic scars
}

\author{
Vinícius Zolezi da Silva ${ }^{1}$, Antonio Albacete Neto ${ }^{1}$, Grazielle de Souza Horácio ${ }^{1}$, Guilherme Augusto Magalhães de Andrade ${ }^{1}$, \\ Leandro Debs Procópio ${ }^{2}$, Pedro Soler Coltro ${ }^{3}$, Jayme Adriano Farina Júnior ${ }^{4 *}$ \\ ${ }^{1}$ Resident Plastic Surgeon, Hospital das Clínicas, Faculdade de Medicina de Ribeirão Preto, Universidade de São Paulo (FMRP-USP), Ribeirão Preto, SP, Brazil \\ 2Plastic Surgeon, Full Member of the Sociedade Brasileira de Cirurgia Plástica (SBCP), Ribeirão Preto, SP, Brazi \\ ${ }^{3}$ PhD Professor, Division of Plastic Surgery, FMRP-USP, Ribeirão Preto, SP, Brazil \\ ${ }^{4}$ PhD Professor and Head of the Division of Plastic Surgery, FMRP-USP, Ribeirão Preto, SP, Brazil
}

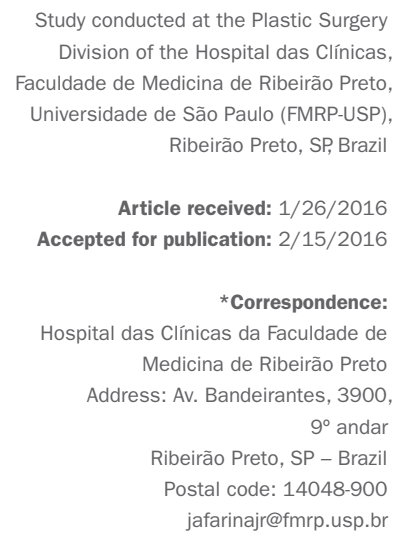

\section{SUMmARY}

Introduction: Since the 1980s, the use of autologous fat grafting has been growing in plastic surgery. Recently, this procedure has come to be used as a treatment for keloids and hypertrophic scars mainly due to the lack of satisfactory results with other techniques. So far, however, it lacks more consistent scientific evidence to recommend its use. The aim of this study was to review the current state of autologous fat grafting for the treatment of keloids and hypertrophic scars, their benefits and scientific evidences in the literature.

Method: A review in the Pubmed database was performed using the keywords "fat grafting and scar", "fat grafting and keloid scar" and "fat grafting and hypertrophic scar." Inclusion criteria were articles written in English and published in the last 10 years, resulting in 15 studies.

Results: These articles indicate that autologous fat grafting carried out at sites with pathological scars leads to a reduction of the fibrosis and pain, an increased range of movement in areas of scar contraction, an increase in their flexibility, resulting in a better quality of scars.

Conclusion: So far, evidences suggest that autologous fat grafting for the treatment of keloids and hypertrophic scars is associated with a better quality of scars, leading to esthetic and functional benefits. However, this review has limitations and these findings should be treated with reservations, since they mostly came from studies with low levels of evidence.

Keywords: cicatrix, keloid, cicatrix hypertrophic, transplantation autologous, adipose tissue.

\section{INTRODUCTION}

Autologous fat grafts have been used since the beginning of the last century to fill in defects in subcutaneous tissue. In the mid-1980s, the technique of liposuction boosted its use by facilitating its acquisition and application. Since then, the number of procedures using autologous fat grafting has grown in several areas, especially in plastic surgery.

Due to the large number of patients with hypertrophic scars and keloids that did not show improvement with the treatments available at the time, new techniques have been used in order to promote scar maturation and obtain esthetic and functional benefits. In this context, autologous fat grafting represents another therapeutic option and has been used on unsightly and retracted scars, ${ }^{1,2}$ burn sequelae, ${ }^{3}$ and in reconstructive and cosmetic surgeries (to improve body contour, with the intention of filling and increasing volume).

Previous studies have shown that there are stem cells derived from adipose tissue in the product of liposuction (ADSC: "adipose-derived stem cell"). These cells produce mediators that stimulate the wound healing process and tissue regeneration, and may lead to obtaining a resulting scar of better quality. ${ }^{4}$ 
Recently, there has been greater promotion of autologous fat grafting at scientific events in our country in order to improve the appearance of keloids and hypertrophic scars, in addition to other benefits. However, currently there is a lack of consistent scientific evidence to recommend autologous fat grafting as a treatment of pathological scars.

The objective of this study was to conduct a review of the current state of autologous fat grafting for the treatment of keloids and hypertrophic scars, its benefits, and scientific evidence present in the literature.

\section{MetHOD}

The research was conducted at the Plastic Surgery Division of the Hospital das Clínicas, University of São Paulo's Ribeirão Preto Medical School (ORDERS-USP), from May 2015 to January 2016. A review of articles relating to the topic on the Pubmed/Medline database was conducted, cross-referencing the following descriptors: "fat grafting and scar", "fat grafting and keloid scar" and "fat grafting and hypertrophic scar".

We found 291 articles related to the topic. The inclusion criteria were articles written in English containing the descriptors stated above and published over the last 10 years, resulting in 15 articles (the most relevant articles were selected by their level of evidence or the data contained therein). Case reports were excluded. In each study the authors sought information concerning the role of autologous fat grafting in the treatment of pathological scars, as well as the evidence for such, and esthetic/functional benefits. The inclusion and exclusion criteria are given in Table 1.

The articles were classified according to their level in the evidence pyramid, ${ }^{5}$ which varies in descending order from I to V, as can be seen in Table 2. Certain studies cannot be classified based on this classification, as is the

TABLE 1 Articles inclusion and exclusion criteria.

\section{Inclusion criteria}

Articles accessed in the Pubmed database

Articles containing the keywords "fat grafting and scar", "fat grafting

and keloid scar" and "fat grafting and hypertrofic scar"

Articles written in English

Articles published in the last 10 years

Exclusion criteria

Case reports

Articles with no data on the use of autologous fat grafting for the

treatment of pathological scars case of animal studies, cadaver studies, review articles, letters and editorials.

\section{RESULTS}

The articles selected for this review point to the results and conclusions presented in Table $3 .^{1-4,6-16}$

Nine of the 15 studies were classified as level IV (case series), two as level III (a retrospective cohort and a comparative clinical study), one as level II (prospective cohort study), and three were not classified (for dealing with animal studies or review articles). No level I studies were found, that is, those with the strongest evidence (controlled and randomized clinical trials).

Animal and in vitro studies revealed that fat grafting also stimulates angiogenesis due to the presence of growth factors such as insulin-like growth factor 1 (IGF-1), platelet derived growth factor (PDGF) and, principally, vascular endothelium growth factor (VEGF), which is critical for angiogenesis and fibrotic tissue replacement. During fat grafting, ADSC have been found, which may regulate vessel density, the granulation process and thickness of collagen, leading to an improved appearance of pathological scars. ${ }^{6}$

There was some variability between the authors as to the inclusion criteria for patient selection. These criteria included hypertrophic scars and keloids without improvement after clinical treatment, burns without improvement after three weeks of treatment and ulcers of various etiologies. As exclusion criteria, some authors used the realization of previous surgeries on the site, ${ }^{6}$ scars over bony prominences and diabetes mellitus, ${ }^{7}$ as well as areas with neoplasia due to the theoretical risk of producing new growth factors at the fat grafting site, in addition to VEGF, which could potentially promote tumor growth and invasion. ${ }^{8}$

Fat grafting was also used in patients with painful and retracted scars, ${ }^{7}$ in post-mastectomy breast reconstructions (showing a reduction of esthetic sequelae such as cicatricial retraction and deformities) ${ }_{,}^{8}$ in cicatricial

\section{TABLE 2 Level of evidence of the types of scientific study.}

\begin{tabular}{ll} 
Level of evidence & Type of scientific study (Treatment) \\
\hline I & High quality randomized controlled clinical trial \\
\hline II & Prospective cohort; prospective comparative study \\
\hline III & $\begin{array}{l}\text { Retrospective cohort; retrospective comparative } \\
\text { study; case-control study }\end{array}$ \\
\hline IV & Case series with pre- and post-test or only post-test \\
\hline V & Case report; opinions developed through consensus \\
\hline
\end{tabular}


TABLE 3 Selected articles, types of study and level of evidence.

\begin{tabular}{|c|c|c|c|}
\hline Author / Year & Conclusion of the article regarding autologous fat grafting & Type of study & Level of evidence \\
\hline \multirow[t]{2}{*}{ Piccolo NS et al., $2015^{3}$} & Decreased fibrosis and hypertrophic scars & Case series & IV \\
\hline & Increase elasticity and scar malleability & & \\
\hline \multirow[t]{2}{*}{ Huang SH et al., $2015^{12}$} & Relief of cicatricial neuropathic pain due to improved quality of & Case series & IV \\
\hline & pathological healing & & \\
\hline \multirow[t]{2}{*}{ Kato $\mathrm{H}$ et al., $2014^{13}$} & Dynamic remodeling of the cicatricial area after fat grafting & Experimental & - \\
\hline & & animal study & \\
\hline \multirow{2}{*}{$\begin{array}{l}\text { Maione L et al., } \\
2014^{7}\end{array}$} & Decreased consistency and size of the pathological scar & Case series & IV \\
\hline & Increased range of movement of the pathological scar & & \\
\hline \multirow{3}{*}{$\begin{array}{l}\text { Balkin DM et al., } \\
2014^{4}\end{array}$} & Decreased scar size & Case series & IV \\
\hline & Improvement of scar color & & \\
\hline & Increased malleability of scar & & \\
\hline \multirow{2}{*}{$\begin{array}{l}\text { Pallua } \mathrm{N} \text { et al., } \\
2014^{6}\end{array}$} & Improvement of the quality, color and malleability of the pathological & Case series & IV \\
\hline & scar & & \\
\hline Moltó Garcia R et al., $2014^{8}$ & Decreased retractions in pathological scars & Case series & IV \\
\hline \multirow[t]{3}{*}{ Maione L et al., $2014^{9}$} & Decreased pain during treatment, and decreased surgical & Comparative & III \\
\hline & complications & clinical study & \\
\hline & Remodeling of the scar architecture & & \\
\hline \multirow[t]{3}{*}{ Mazzola IC et al., $2013^{10}$} & Improvement in esthetics and function of the area with pathological & Case series & IV \\
\hline & healing & & \\
\hline & Low rate of surgical complications & & \\
\hline \multirow[t]{2}{*}{ Viard R et at., $2012^{14}$} & Increased softness of the pathological scar & Case series & IV \\
\hline & Remodeling in areas with lack of subcutaneous volume & & \\
\hline \multirow[t]{2}{*}{ Guisantes E et al., $2012^{1}$} & Decreased scar retraction & Case series & IV \\
\hline & Improvement of pathological scar depression & & \\
\hline \multirow{2}{*}{$\begin{array}{l}\text { Sultan SM et al., } \\
2011^{11}\end{array}$} & Decreased scar fibrosis & Experimental & - \\
\hline & Improvement of cicatricial quality with increased revascularization & animal study & \\
\hline \multirow[t]{2}{*}{ Caviggioli F et al., $2011^{15}$} & Improvement of quality, and improvement of cicatricial pain & Prospective & II \\
\hline & & cohort study & \\
\hline \multirow[t]{2}{*}{ Clauser LC et al., $2011^{16}$} & Esthetic and functional improvement of the pathological scar & Retrospective & III \\
\hline & & cohort study & \\
\hline Patel N, $2008^{2}$ & Improvement of texture and elasticity in the pathological scar & Review & - \\
\hline
\end{tabular}

sequelae associated with chronic pain, ${ }^{9}$ in post-traumatic pathological cicatricial deformities (with important benefits in tissue texture and elasticity), ${ }^{2}$ in hypertrophic scars after tracheostomy (with better esthetic and functional quality) ${ }^{10}$ and, lastly, in hypertrophic scars and keloids after burns (demonstrating correction of retracted or depressed scars). ${ }^{1}$

\section{Discussion}

In this review, certain authors suggest that fat grafting in cicatricial areas has been used due to the benefits of the ADSC with potential for differentiation in other tissues. In the last decade, recognition of the regenerative poten- tial of fatty tissue has indicated clinical improvement of hypertrophic scars in burn patients. ${ }^{11}$ The use of fat grafting has been extended even for the treatment of neuropathic pain originating from scar tissue, with improvement in the postoperative period of such patients. ${ }^{12}$

In most of the articles analyzed, the Coleman technique $^{17}$ was used as the standard for obtaining the fatty tissue for realization of the autologous fat graft. Generally speaking, the procedure presented a low rate of surgical complications and satisfactory evolution in the postoperative period. ${ }^{15}$ A study by Moltó Garcia et al. showed a rate of $3.35 \%$ for early complications from fat grafting, such as pain at the application site, seroma and 
infection of the surgical wound. In relation to late-onset complications, this study indicated the presence of cysts at the fat grafting site ( $16.2 \%$ of cases) and calcifications (10.8\% of cases). ${ }^{8}$

Some studies suggest that autologous fat grafting improves the quality of hypertrophic scars and keloids by presenting a large amount of stem cells and growth factors. As such, this could contribute to decreased fibrosis and increased elasticity, promoting increased malleability of pathological scars. ${ }^{3}$ In addition, there is evidence of benefits to scars that have pathological retractions, resulting in clinical improvement and a gain in the amplitude of movements. ${ }^{7}$ However, since these studies ${ }^{3,7}$ are classified as case series (level IV), any conclusions remain limited by the low level of evidence.

According to some studies, the benefit of ADSC does not appear to be merely theoretical, as they promote increased angiogenesis, the formation of granulation tissue and re-epithelialization, improve color, and may lead to less visible scarring (Figure 1) and increased malleability of the scar. ${ }^{4,9}$ Histological studies carried out in areas of fat grafting have indicated that mesenchymal stem cells promote architectural remodeling in the scar tissue, as well as angiogenesis and improved local hydration, leading to increased malleability of the scar. ${ }^{9}$

In relation to hypertrophic scars and keloids in burn patients, fat grafting resulted in accelerated revascularization of the scar tissue associated with decreased fibrosis. This improvement may be related to an increase in VEGF, with a reduction of fibrosis markers verified using ELISA and PCR. This early revascularization could be a protective factor of the wound due to increased tissue transforming growth factor beta 1 (TGF- $\beta 1$ ), resulting in a breakdown in the synthesis of collagen in the beginning of the pathological scar formation. ${ }^{11}$

One of the limitations of this review is that most of the studies analyzed (nine articles out of a total of 15) were classified as cases series (evidence level IV). This indicates that most of the data relating to autologous fat grafting in the treatment of pathological scars originated from studies located in the lower levels of the evidence pyramid, meaning that the results and conclusions should be analyzed critically and with some reservation. For this reason, we believe that there is a lack of more consistent evidence for the recommendation of autologous fat grafting in the treatment of keloids and hypertrophic scars.

Finally, new studies with the strongest level of evidence (randomized and controlled clinical trials, prospective cohort studies, and comparative studies with control groups) are required in order to elucidate some of the gaps in our knowledge concerning the role of autologous fat grafting in pathological scars, for example, the standardization of surgical indication, more prolonged postoperative monitoring assessment of late-onset results, the systematization of conduct and proof of the role of ADSC in the promotion of cicatricial improvement.

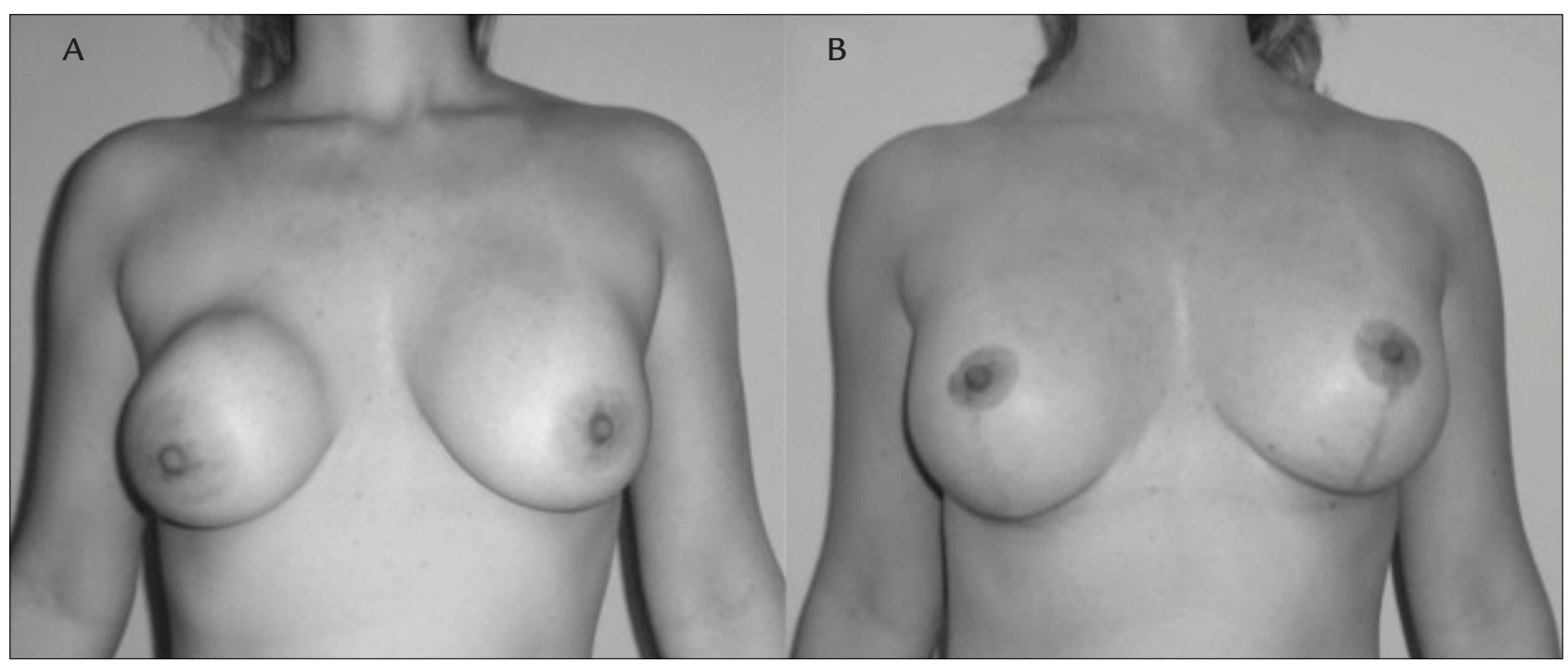

FIGURE 1 A. A 40-year-old female patient who underwent mammoplasty 10 years before and developed capsular contracture on the right. B. She was submitted to a change of implant and bilateral mastopexy associated with fat grafting (60 $\mathrm{mL})$ to the right breast only, in order to improve the contour. Note the improved quality of the scars on the right breast, which are less evident in relation to the left. 


\section{Conclusion}

Up to now, the evidence indicates that autologous fat grafting for the treatment of hypertrophic scars and keloids is associated with decreased local fibrosis, increased scar malleability and greater range of motion in areas of cicatricial retraction, leading to esthetic and functional benefits. However, this review has limitations and the findings must be noted with reservations, given that the majority of these findings originated from studies with low levels of evidence.

\section{Resumo}

Evidências da lipoenxertia autóloga para o tratamento de queloides e cicatrizes hipertróficas

Introdução: a partir da década de 1980, o uso da lipoenxertia autóloga tem crescido na cirurgia plástica. Recentemente, esse procedimento passou a ser utilizado como tratamento de queloides e cicatrizes hipertróficas, principalmente em decorrência da falta de resultados satisfatórios com outras técnicas. No entanto, até o momento, faltam evidências científicas mais consistentes que recomendem seu uso. O objetivo deste estudo foi realizar uma revisão do estado atual da lipoenxertia autóloga no tratamento de queloides e cicatrizes hipertróficas, os benefícios e as evidências científicas presentes na literatura.

Método: foi realizada uma revisão na base de dados Pubmed com os descritores "fat grafting and scar", "fat grafting and keloid scar" e "fat grafting and hypertrofic scar". Os critérios de inclusão foram artigos escritos em inglês e publicados nos últimos 10 anos, resultando em 15 estudos.

Resultados: os artigos indicam que a lipoenxertia autóloga realizada em locais com cicatrizes patológicas leva a uma diminuição da fibrose e da dor, à maior amplitude de movimentos em áreas de retração cicatricial, ao aumento de sua maleabilidade, resultando na melhor qualidade das cicatrizes.

Conclusão: até o momento, as evidências sugerem que a lipoenxertia autóloga para o tratamento das queloides e cicatrizes hipertróficas está associada à uma melhor qualidade das cicatrizes, levando a benefícios estéticos e funcionais. Contudo, esta revisão possui limitações e os achados devem ser analisados com ressalvas, já que a maioria provem de estudos com baixos níveis de evidência.

Palavras-chave: cicatriz, queloide, cicatriz hipertrófica, transplante autólogo, tecido adiposo.

\section{References}

1. Guisantes E, Fontdevila J, Rodríguez G. Autologous fat grafting for correction of unaesthetic scars. Ann Plast Surg. 2012; 69(5):550-4.

2. Klinger M, Marazzi M, Vigo D, Torre M.Fat injection in severe burn outcomes: a new perspective of scar remodeling and reduction. Aesth Plast Surg. 2008; 32(3):470-2.

3. Piccolo NS, Piccolo MS, Piccolo MT. Fat grafting for treatment of burns, burn scars, and other difficult wounds. Clin Plast Surg. 2015; 42(2):263-83.

4. Balkin DM, Samra S, Steinbacher DM. Immediate fat grafting in primary cleft lip repair. J Plast Reconstr Aesth Surg. 2014; 67(12):1644-50.

5. Sullivan D, Chung KC, Eaves FF, Rohrich RJ. The level of evidence pyramid: indicating levels of evidence in plastic and reconstructive surgery articles. Plast Reconstr Surg. 2011; 128(1):311-4.

6. Pallua N, Baroncini A, Alharbi Z, Stromps JP. Improvement of facial scar appearance and microcirculation by autologous lipofilling. J Plast Reconstr Aesth Surg. 2014; 67(8):1033-7.

7. Maione L, Memeo A, Pedretti L, Verdoni F, Lisa A, Bandi V, et al. Autologous fat graft as treatment of post short stature surgical correction scars. Injury. 2014; 45(Suppl 6):S126-32.

8. Moltó García R, González Alonso V, Villaverde Doménech ME. Fat grafting in immediate breast reconstruction. Avoiding breast sequelae. Breast Cancer. 2016; 23(1):134-40

9. Maione L, Vinci V, Caviggioli F, Klinger F, Banzatti B, Catania B, et al. Autologous fat graft in postmastectomy pain syndrome following breast conservative surgery and radiotherapy. Aesthetic Plast Surg. 2014; 38(3):52832.

10. Mazzola IC, Cantarella G, Mazzola RF. Management of traqueostomy scar by autologous fat transplantation: a minimally invasive new approach. J Craniofac Surg. 2013; 24(4):1361-4.

11. Sultan SM, Barr JS, Butala P, Davidson EH, Weinstein AL, Knobel D, et al. Fat grafting accelerates revascularisation and decreases fibrosis following thermal injury. J Plast Reconstr Aesth Surg. 2012; 65(2):219-27.

12. Huang $\mathrm{SH}$, Wu SH, Chang KP, Lin CH, Chang $\mathrm{CH}$, Wu YC, et al. Alleviation of neuropathic scar pain using autologous fat grafting. Ann Plast Surg. 2015; 74(Suppl 2):S99-104.

13. Kato H, Mineda K, Eto H, Doi K, Kuno S, Kinoshita K, et al. Degeneration, regeneration, and cicatrization after fat grafting: dynamics total tissue remodeling during the first 3 months. Plast Reconstr Surg. 2014; 133(3):303e-13e.

14. Viard R, Bouquila J, Voulliaume D, Comparin JP, Dionyssopoulos A, Foyatier JL. [Fat grafting in facial burns sequelae]. Ann Chir Plast Esthet. 2012; 57(3):217-29.

15. Caviggioli F, Maione L, Forcellini D, Klinger F, Klinger M. Autologous fat graft in postmastectomy pain syndrome. Plast Reconstr Surg. 2011; 128(2):349-52.

16. Clauser LC, Tieghi R, Galiè M, Carinci F. Structural fat grafting: facial volumetric restoration in complex reconstructive surgery. J Craniofac Surg. 2011; 22(5):1695-701

17. Coleman SR. Structural fat grafting: more than a permanent filler. Plast Reconstr Surg. 2006; 118(3 Suppl):108S-20S 